GEAP-10114 AEC RESEARCH AND DEVELOPMENT REPORT OCTOBER 1969
RECEIVED BY DTIE MAY 111970

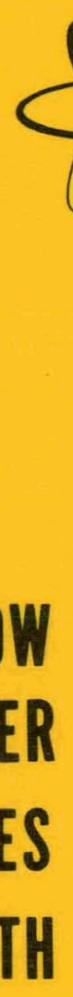

\title{
QUARTERLY PROGRESS REPORT JULY 1 - SEPTEMBER 30, 1969
}

U.S. ATOMIC ENERGY COMMISSION CONTRACT AT(04-3)-189 PROJECT AGREEMENT 44 


\section{DISCLAIMER}

This report was prepared as an account of work sponsored by an agency of the United States Government. Neither the United States Government nor any agency Thereof, nor any of their employees, makes any warranty, express or implied, or assumes any legal liability or responsibility for the accuracy, completeness, or usefulness of any information, apparatus, product, or process disclosed, or represents that its use would not infringe privately owned rights. Reference herein to any specific commercial product, process, or service by trade name, trademark, manufacturer, or otherwise does not necessarily constitute or imply its endorsement, recommendation, or favoring by the United States Government or any agency thereof. The views and opinions of authors expressed herein do not necessarily state or reflect those of the United States Government or any agency thereof. 


\section{DISCLAIMER}

Portions of this document may be illegible in electronic image products. Images are produced from the best available original document. 


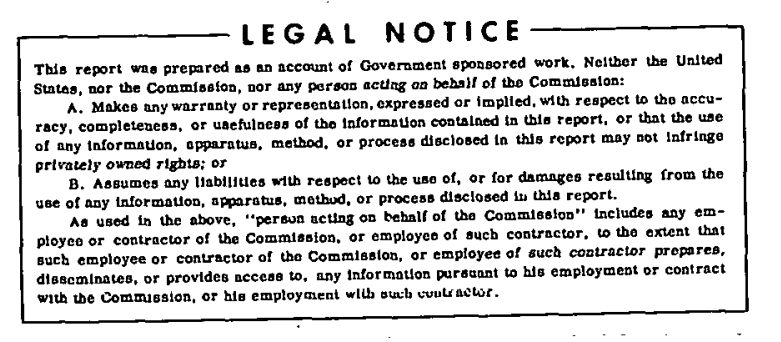

(i) $\mid$ AP- -1011.4

AF( Research and Irvelopment Report ()ctober 1960

\section{TWO.PHASE FLOW AND IIEAT TRANSFER IN MULTIROD GEOMETRIES}

\section{Sixteenth Quarterly Progress Report \\ July 1-September 30, 1969}

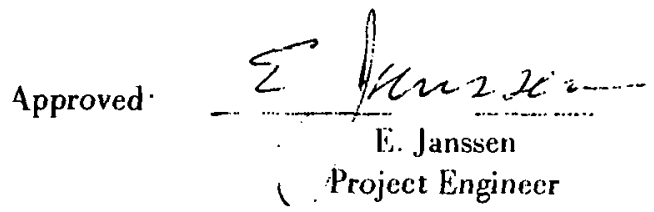

Approved:

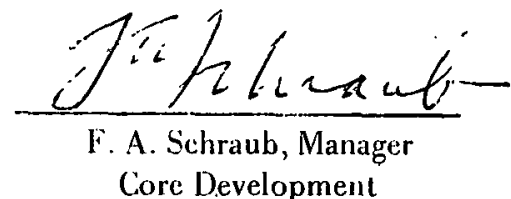

1!. S. Alomic Energy Commission Contract AT(03-4)-1.89

Project Agreement 44

Printed in U.S.A. Available from the Clearing House for Federal Srientific and Technical Information Natiunal Bureau of Standards, Li. S. Department of Commerce. Springfield, Virginia

Price: $\$ 3.00$ per copy 


\section{LEGAL NOTICE}

This report was prepared as an account of Government sponsored work. Neither the United States, nor the Commission, nor any person acting on behalf of the Commission:

A. Makes any warranty or representation, expressed or implied, with respect to the accuracy, completeness, or usefulness of the information contained in this report, or that the use of any information, apparatus, method, or process disclosed in this report may not infringe privately owned rights; or

B. Assumes any liabilities with respect to the use of, or for damages resulting from the use of any information, apparatus, method, or process disclosed in this report.

As used in the above, "person acting on behalf of the Commission" includes any employee or contractor of the Commission, or employee of such contractor, to the extent that sucb employee or contractor of the Commission, or employee of sucb contractor prepares, disseminates, or provides access to, any information pursuant to bis employment or contract with the Commission, or bis employment with such contractor. 
TABLE OF CONTENTS

Acknowledgments . . . . . . . . . . . . . . . . . 1

Summary . . . . . . . . . . . . . . . . . . . . 1

1. Introduction . . . . . . . . . . . . . . . . . . . 1

2. Description of Circular Tube Test Section … . . . . . . . . . . 2

References ....................... 12

Distribution ..... . . . . . . . . . . . . . 12 


\section{LIST OF ILLUSTRATIONS}

Figure

I Circular T'ube Test Section

Segment of Test Section between Power l.ead Attachment Points $E_{2}$ and $E_{3}$. (Foil insulation, ordinarily in place, was removed for this photo.)

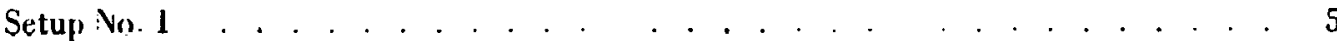

4 Schematic of Loop with Setup No. 1 . . . . . . . . . . . . . . . . . . 6

5 Top of Test Section with Setup No. l. (Foil insulation was removed for this photo.) . . 7

h Closeup of Top of Test Section with Setup No. I. Top Closure Removed . . . . . 8

Setup No. 2

. 10

8 


\section{ACKNOWLEDGMENTS}

This program is sponsored by the Atomic Energy Commission and conducted by the General Electric Company, with the following individuals contributing to the program during the current reporting period:

Project Engineer

Engineers.

E. Janssen J. A. Kervinen
R. T. Lahey

D. W. Radcliffe

B. S. Shiralkar

C. C. Smith

Engineering Assistants

Sheila Kiernan

Y. H. Kong

\section{SUMMARY}

\section{Task C}

The circular tube test section, which was built specially for the measurement of developing two-phase flow, in described.

\section{INTRODUCTION}

This is the sixteenth quarterly report on the work done under Contract AT(04-3)-189, Project Agreement No. 44, and covers the period from July 1 to September $30,1969$. follows.

The objectives for Phase 1 of the program were as

Task A

1. Obtain detailed measurements of flow structure (pressure drop, liquid film thickness, wall shear stress, local mass flux, local impact pressure) for air-water and steam-water mixtures.

2. Carry on an analytical effort in parallel with the air-water tests.

\section{Task B}

1. Measure the critical heat flux for a vertical nine-rod geometry, under forced convection conditions, with water at high pressure (600 to 1400 psia) and flow upward. Tests should be performed with a "clean" multirod geometry (as little disturbance as possible to the flow by the provisions for maintaining the rods in correct relative alignment).

2. Investigate the effect of certain parameters; specifically, quality, flow rate, heated length, pressure, and rod-wall spacing.

3. Use the results to evaluate one or more computer models as a basis for CHF prediction.

The work under Phase 1 has been reported in Quartcrly Reports Nús. 1 thruugh 10, plus certain topical reports and summary reports, either issued or to be issued soon.
The objectives for Phase 2 are as follows.

\section{Task C}

1. Make measurements of both fully-developed and developing two-phase flow (steam-water at 600 to 1400 psia, adiabatic and with heat addition; flow vertical upward) from which can be determined rates of mass and energy transfer in the transverse direction, such measurements to be made in a circular tube, eccentric annulus, and nine-rod channel. The nine-rod channel measurements should include representative measurements of subchannel flow and enthalpy from which can be deduced information concerning cross flow and mixing.

2. Determine the relationships between rate and driving potential, or potential gradient, and the effect of certain parameters (e.g., total flow, pressure, local void) on these relationships. In particular, determine the effect of grid-type spacers in the nine-rod channel.

3. Analyze the results to evaluate existing models of two-phase flow. Endeavor to develop an improved model in light of the results. Such a model should be useful in the prediction of flow structure, pressure. drop, and critical heat flux in developing two-phase flow in multirod geometries, both "clean" and with grid-type spacers.

\section{Task D}

1. Measure critical heat flux in a nine-rod channel fitted with grid-type spacers characteristic of modern watercooled reaclurs. 
2. Determinc, if possible, whether, and to what degree, the effect of spacers on the CHF is caused by a redistribution of the flow among the various subchannels, or by a highly localized disturbance which might, for example, disrupt the liquid film.

3. Modify the prediction methods developed in Task $\mathrm{C}$ as appropriate, and check them against the data obtained under Item 1.

Subchannel measurements under Task $C$ were continued in the nine-rod test section during July and part of August. These measurements were made with the heat flux nonuniform in the radial direction, in contrast with the carlier measurements for which the heat flux was uniform. These. plus the earlicr subchannel results given in References 1 and 2 , will be presented in detail in a topical report to be issued soon. No further description of the subchannel work will be given here.

The circular tube test section for the measurement of fully-developed and developing two-phase flow under Task C. was completed and put into service in September. Some data were obtained but have not been reduced. Comments in this report will be confined to only a description of the test section.

\section{DESCRIPTION OF GIRCULAR TUBE TEST SECTION}

The circular tube test section shown in Figures 1 and 2 was designed and built specially for the measurement of developing two-phase flow. It has an inside diameter of $0.683 \mathrm{inch}$, and has various points of attachment for the electrical power leads so that measurements may be made either at the end of the heated length or at various distances past the end of the heated length. The different possible arrangements are:

$\begin{array}{cc}\begin{array}{c}\text { Heated } \\ \text { Length } \\ \text { (ft) }\end{array} & \begin{array}{c}\text { Distance from Heated Length } \\ \text { to Exit End of Tube } \\ \text { (ft) }\end{array} \\ 15.8 & \\ 1 & 8 \\ 6 & 4 \\ 8 & 2 \\ & 0\end{array}$

\subsection{SETUP NO. 1}

The flow at the exit end of the tube can be divided by means of a concentric cylindrical flow splitter into an inner zone and an ouler zone, which in an annular flow regime correspond approximately to the core region and the film region, respectively. This setup with flow splitter in place is shown in Figures 3 through 6 , and is hereinafter referred to as Setup No. 1.

Static pressure taps located on the wall and on the centerline at the leading edge of the splitter are used to adjust the flow in the outer zone so that the flow at the leading edge is "isokinetic". The flow is presumed to be isokinetic (i.e., unchanged by the means used to measure it) when the static pressures on the wall and centerline are equal. Three different diameter splitters are used in order to traverse the film region. The annular clearance between the largest diameter splitter (No. 1) and the tube wall is $0.0 \mathrm{i}$ inch. The annular clearances for the other two splitters (Nos. 2 and 3) are 0.02 inch and 0.03 inch, respectively.
Setup No. 1 also includes the eight static pressure taps shown in Figure 1 for static pressure gradient determination.

The inner-zone and outer-zone flows-which will be referred to, respectively, as the main flow and the sample flow in the following discussion-leave the test section through concentric passageways (see Figure 3). The main flow is in the outer passage and acts as a steam-water jacket around the sample flow, to minimize heat loss from the sample. The main flow then goes to an afterheater and steam drum and the sample goes to a mixer-type calorimeter, as shown in Figure 4. The sample is mixed with a measured ratc of cold water which condenses any steam in the sample. The rate and enthalpy of the mixture and the increase in enthalpy of the cold water in going through the calorimeter, are sufficient lu determinc the cample rate and enthalpy. A slight .correction is necessary to account for heat loss from the calorimetcr itself.

The quantities that are measured in Setup No. 1 are:

- System pressure (at exit end of test section)

- Total flow rate (just ahead of test section inlet)

- Inlet temperature

- Power to test section

- Exit temperature

- Cold water flow rate

- Cold water temperature

- Mixture (cold water plus sample) flow rate

- Mixture temperature

- Static pressure profile over the last eight feet ahead of the exit.

Various values of inlet temperature and power are used in combination with the various splitters and points of power lead attachment, to determine the effect of mass ratc, quality, and distance from the end of the heated length, on the sample flow in three different annular zones and on the static pressure gradient. 


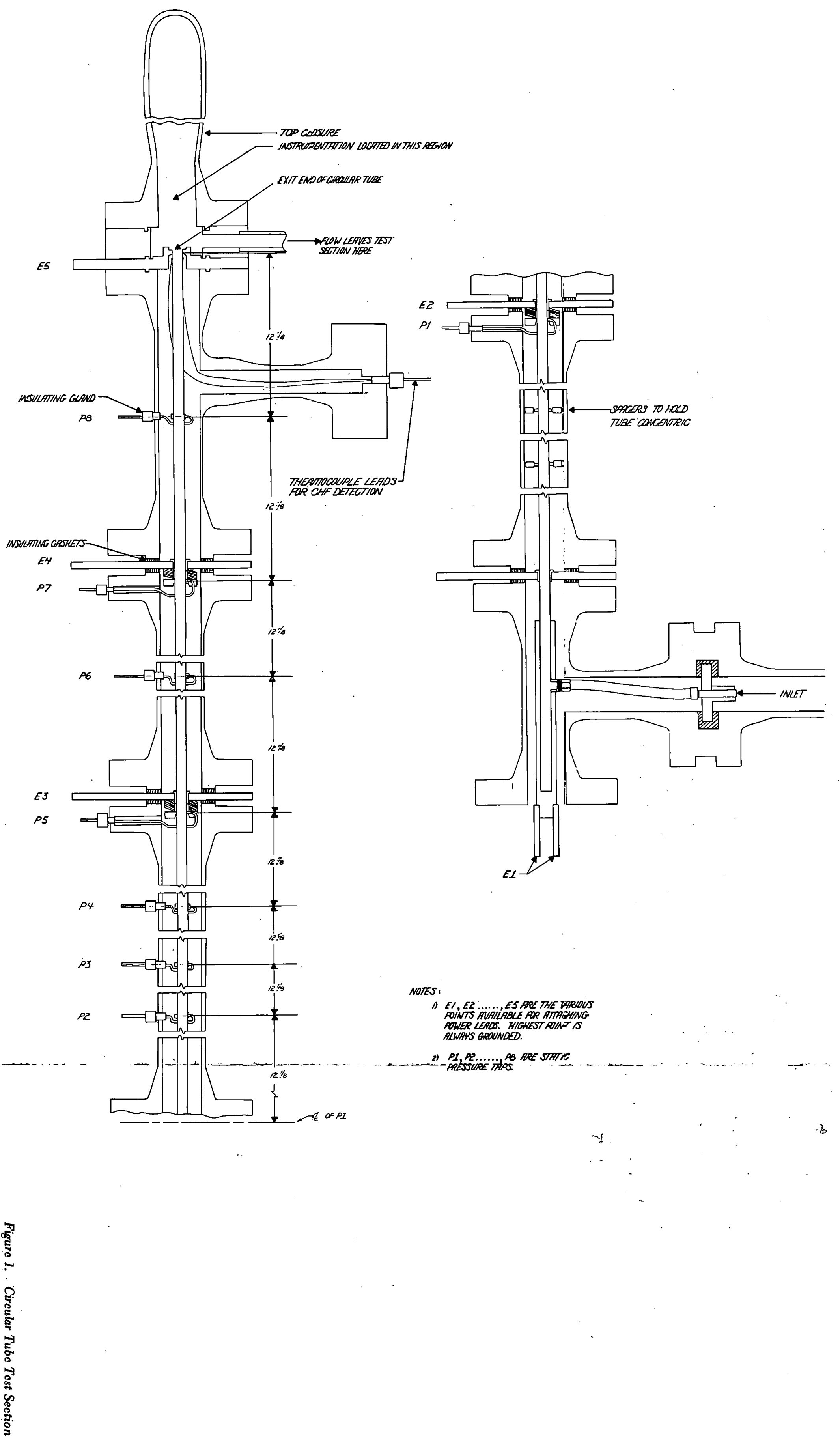




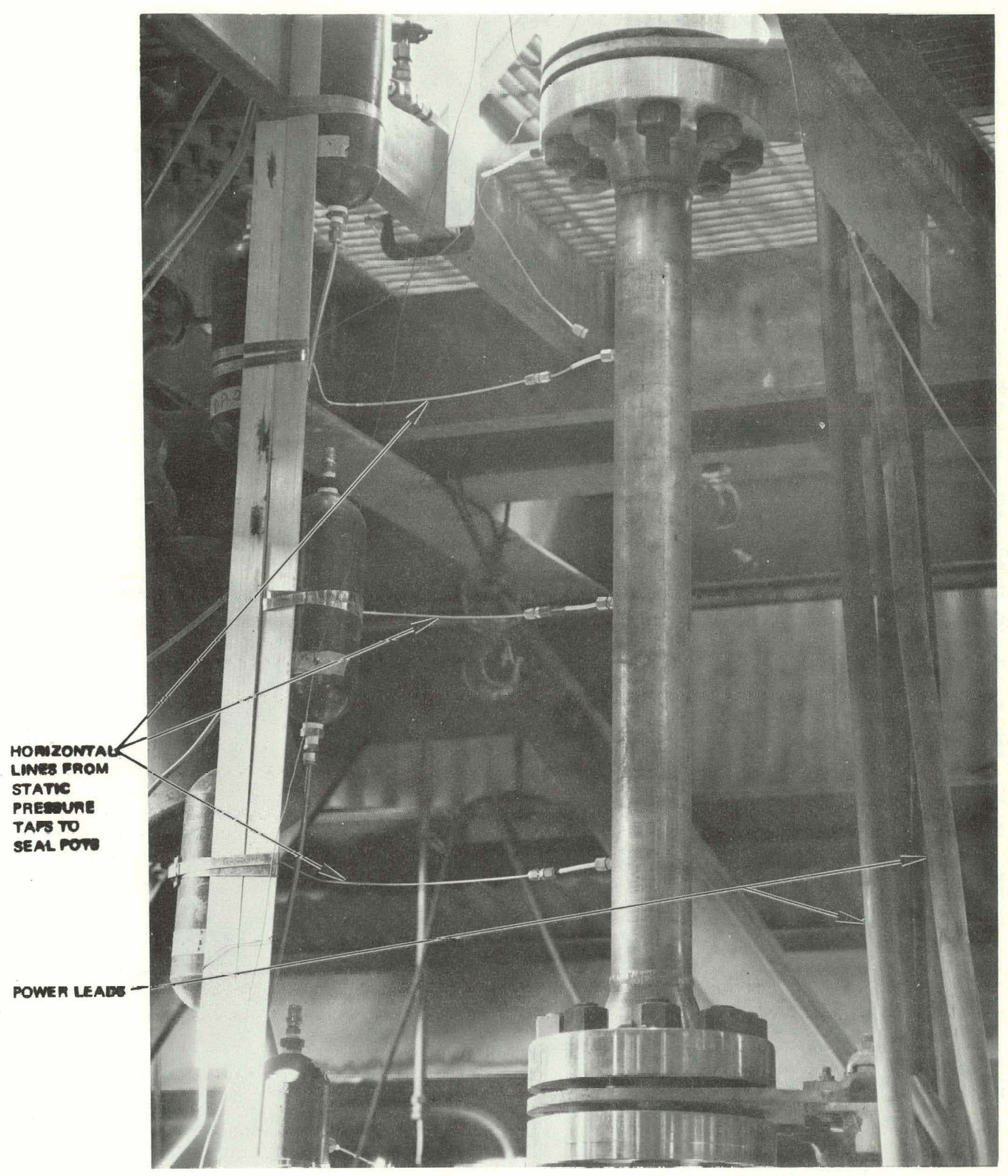

Figure 2. Segment of Test Section between Power Lead Attachment Points $E_{2}$ and $E_{3}$. (Foil insulation, ordinarily in place, was removed for this photo.) 


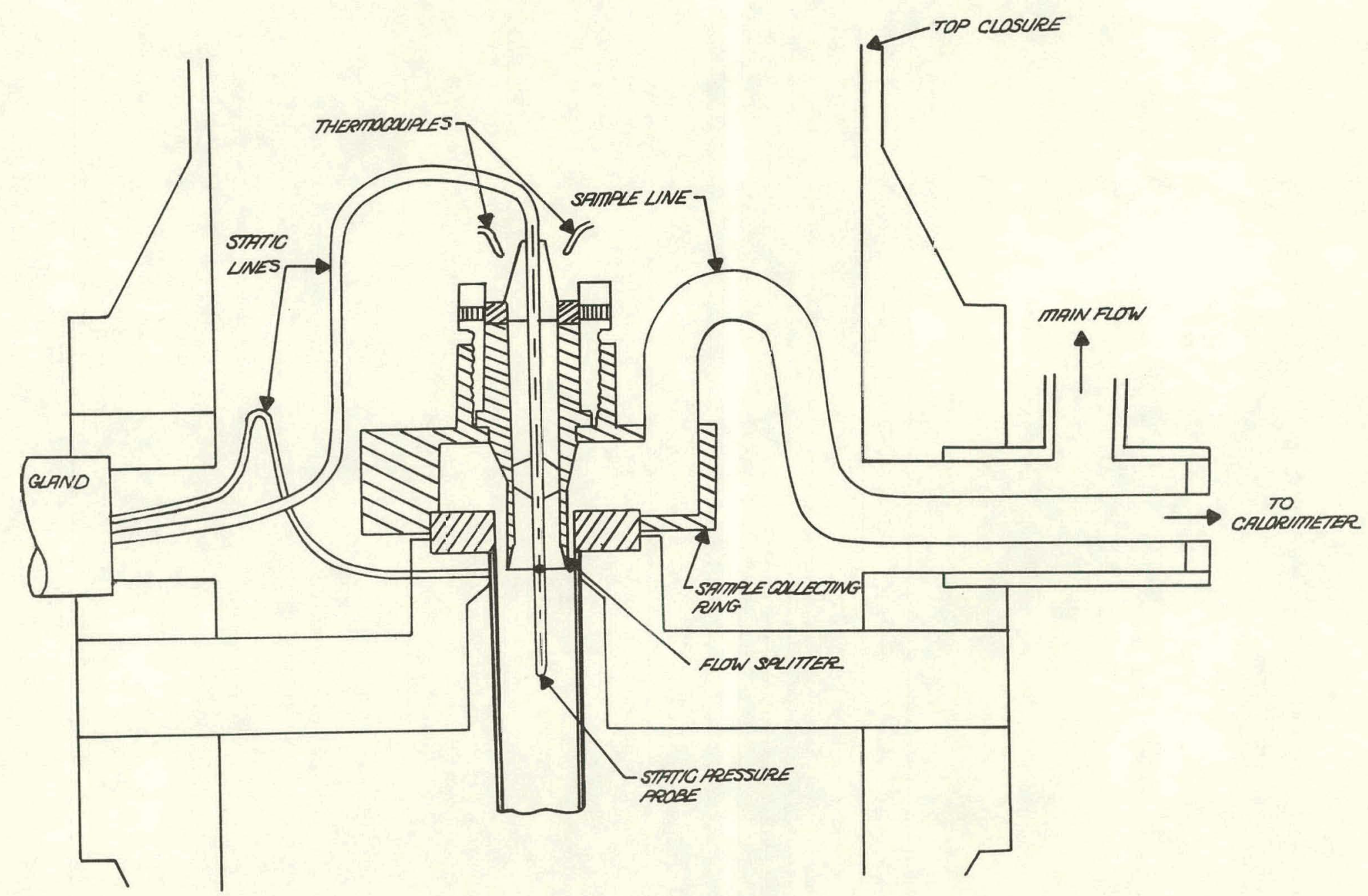




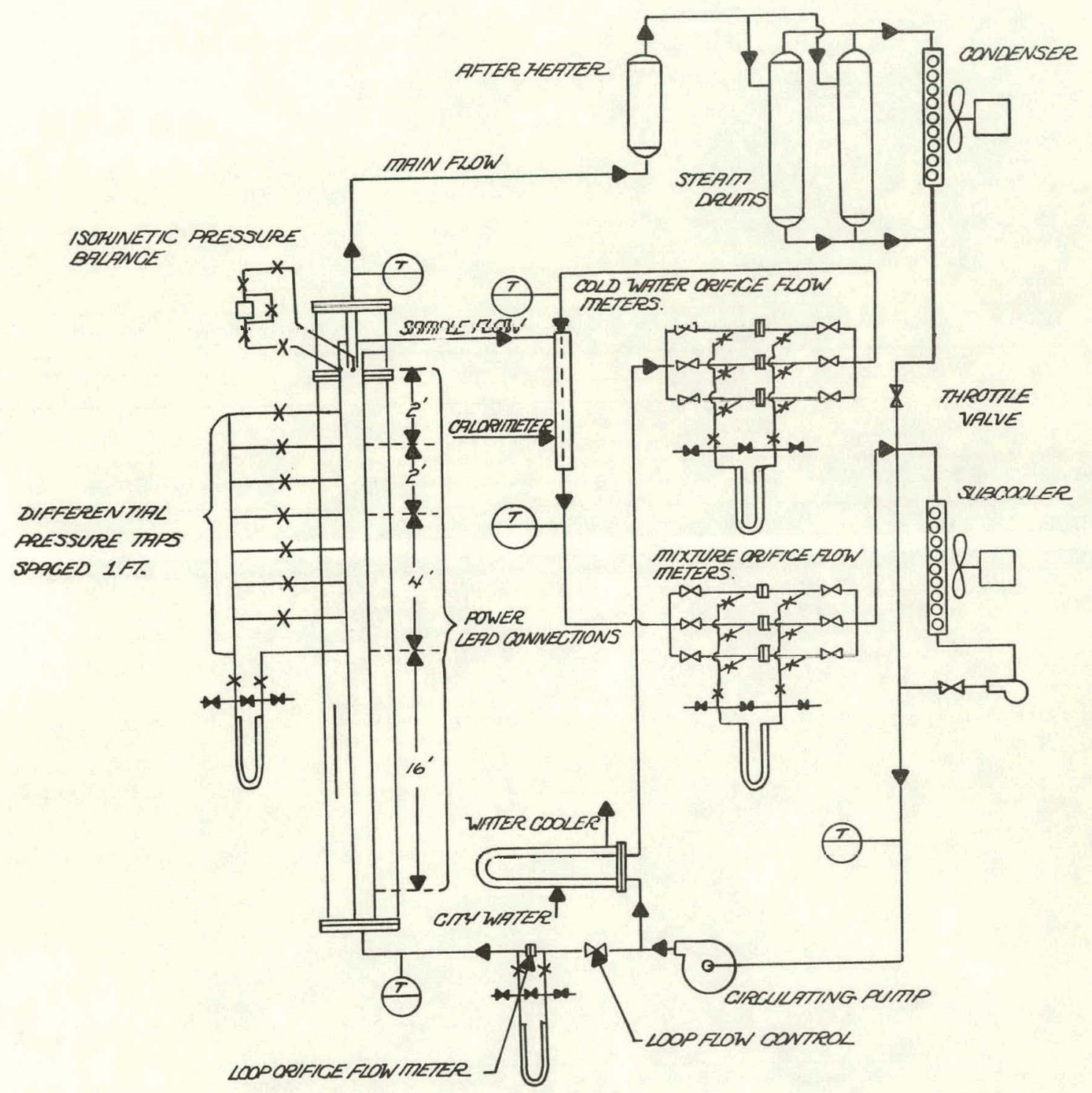

Figure 4. Schematic of Loop with Setup No. 1 


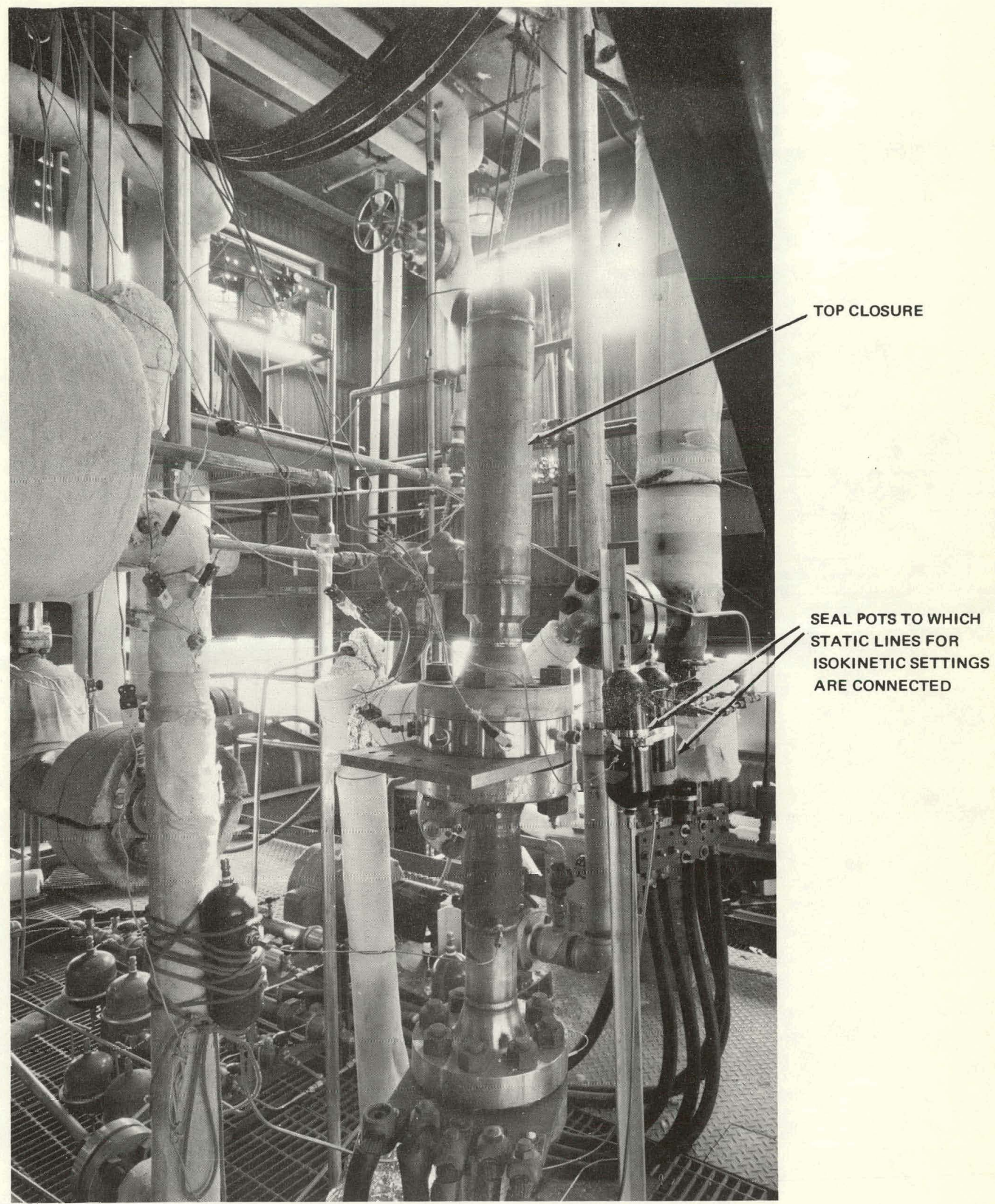

Figure 5. Top of Test Section with Setup No. 1. (Foil insulation was removed for this photo.) 


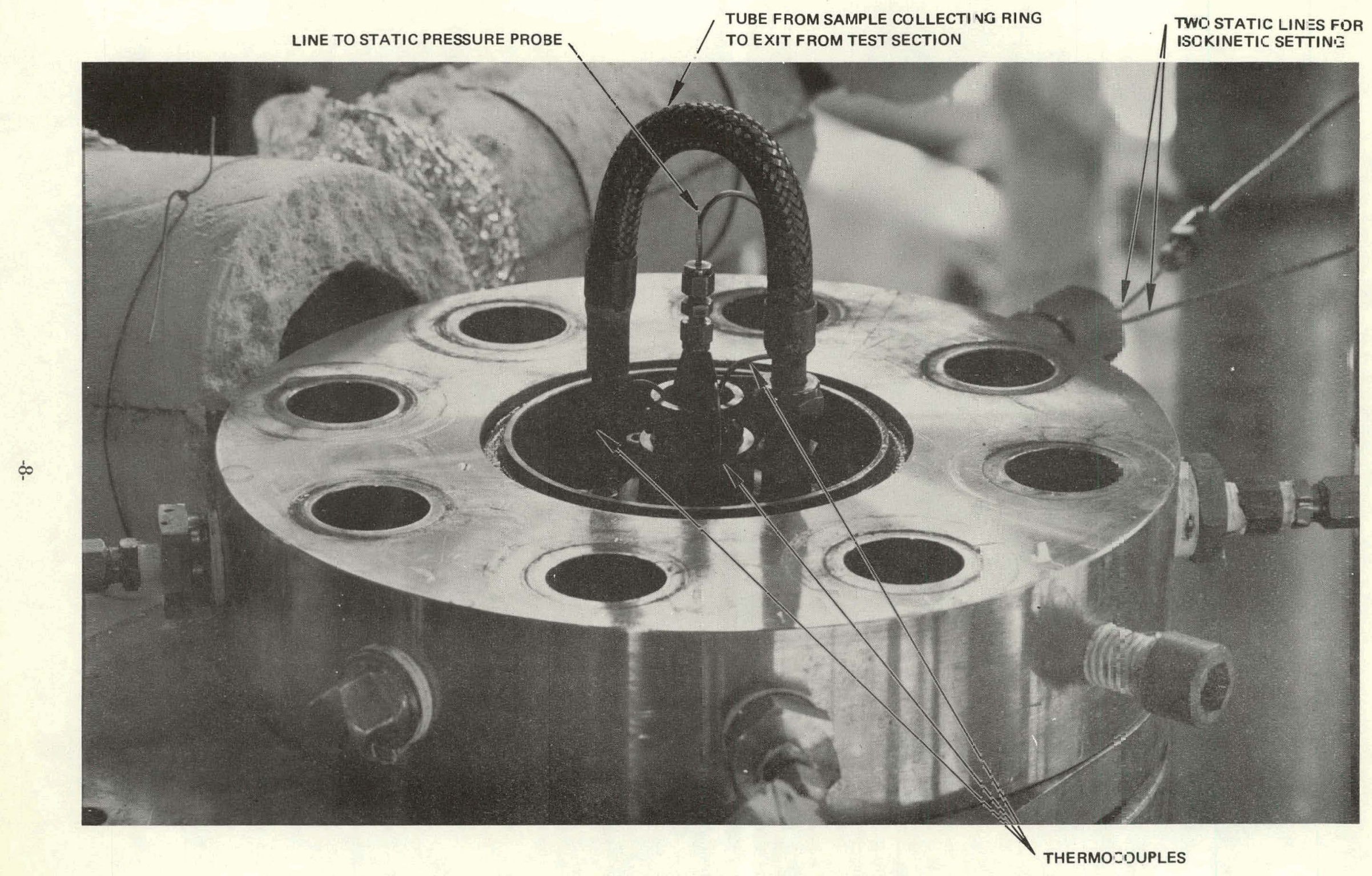




\subsection{SETUP NO. 2}

The thickness of the liquid film* at the exit end of the tube: under conditions of annular flow can be measured by two different schemes, both dependent on the fact that the liquid phase is a much better electrical conductor than the vapor phase. The essential element in the first scheme will be relerred to as a conductivity cell, and in the second as a conductivity probe.

The cell method has been developed and used particularly by the British at Harwell. ${ }^{3,4,5,6}$.It consists essentially of two electrodes embedded in and flush with the wall of the channel. The wall in the vicinity of the electrodes must be of a nonconducting material. Electrical conductance is established between the two electrodes when a continuous film of liquid bridges the gap between them. If the thickness of the liquid film increases, the conductance also increases. If the conductivity cell has been calibrated and the specific conductivity of the liquid is known or constant, the prohlem of measuring film thickness is reduced to the problem of measuring electrical conductance. The cell method gives a value for film thickness which is equal to the thickness of a uniform liquid film (no vapor entrained) having the same conductance.

The probe method has been developed and used by McManus, ${ }^{7}$ Hewitt, et al., ${ }^{5}$ and Bergles, et al. ${ }^{8}$ It consists of a conducting probe which is inserted through one wall of a channel so that it can traverse normal to the opposite wall. When fully inserted, it must make electrical contact with the opposite wall; hence, that wall must be an electrical conductor at the point of contact. As the probe is withdrawn, it first loses direct contact with the wall, but maintains contact via a continuous bridge of liquid in the film. As the probe is further withdrawn, the bridge of liquid becomes discontinuous (as though the probe has encountered the troughs of occasional passing waves), and finallyprovided the flow regime is truly annular-there is no bridge at all (as though the probe has cleared the crests of all passing waves). Following McManus, ${ }^{7}$ the average thickness of the film is taken as the distance that the probe travels from the wall before the probe loses contact with the liquid bridge $50 \%$ of the time.

It is expected that the probe method will give values for film thickness which are greater than the cell method. The reason is that entrained vapor bubbles will, in effect, reduce the specific conductivity of the liquid in the film. The film must necessarily be thicker than is indicated by the cell method in order to have the same conductance as a liquid film free of entrained vapor bubbles.

* This is a generally accepted concept of the annular and annular-dispersed flow regimes. However, the "liquid film" is known to carry entrained vapor, and the interface between liquid and vapor is often very poorly defined. The idea of a film is an oversimplification which is often used in models of these flow regimes.
Setup No. 2, with the conductivity probe and five conductivity cells in place, is shown in Figure 7. The conductivity probe and the first cell are at Station No. 1. The remaining four cells are at Stations Nos. 2 through 5. The sectional view of a typical conductivity cell shows that each cell is actually four cells, each of the four covering a 90-degree sector. Thus, any substantial circumferential variations in film thickness can be detected. Moreover, the axial disposition of the conductivity cell permits detailed determination of thickness variation in the axial direction.

Each of the conductivity cells consists of a ceramic cylinder, with 0.029-inch-diameter stainless steel electrodes which pass through its wall from the outside. The electrodes are brazed to the ceramic and ground flush on the inside. A 0.063-inch-o.d. stainless steel tube is brazed to the outside of the cylinder concentric with each electrode, and the space between each electrode and its tube is filled with insulating material. The tubes are then led out through glands in the wall of the test vessel.

When the conductivity probe is in use for film thickness measurement, one of the conductivity cell electrodes is used in conjunction with it to make the wall a conductor at the point of contact where the probe is fully inserted. A sectional view of the probe is shown in Figure 8. It passes through a water-cooled O-ring gland, and is driven in or out by means of a micrometer screw, with its dial graduated in thousandths of an inch. The center of the probe is an electrically conducting rod, insulated from the surroundings except for a small, sharp point on the inside end and a terminal on the outside end, external to the test section. In use, this terminal is connected to an oscillograph via suitable circuit, to indicate whether or not a continuous bridge of water exists between the probe and the channel wall.

In summary, the liquid film thickness can be measured by either or both methods at the following distances from the end of the heated length:

\begin{tabular}{|c|c|c|c|}
\hline & \multicolumn{2}{|c|}{ Distance from Heated } \\
\hline \multicolumn{2}{|c|}{$\begin{array}{l}\text { Length to Point } \\
\text { of Measurement }\end{array}$} & \multicolumn{2}{|c|}{$\begin{array}{c}\text { Method of } \\
\text { Measurement }\end{array}$} \\
\hline (inches) & (feet) & Cell & Probe \\
\hline 0.75 & & $\mathrm{X}$ & $\mathbf{X}$ \\
\hline 2.75 & & $\mathbf{X}$ & \\
\hline 5.5 & & $\mathrm{X}$ & \\
\hline 11.0 & & $\mathrm{x}$ & \\
\hline 22.0 & & $\mathrm{X}$ & \\
\hline & 2 & $\mathrm{X}$ & $\mathrm{X}$ \\
\hline & 4 & $\mathrm{X}$ & $\mathrm{X}$ \\
\hline & 8 & $\mathrm{X}$ & $\mathrm{X}$ \\
\hline
\end{tabular}

The quantities that are measured in Setup No. 2, then, arc:

- System pressure

- Tulal fluw rate 

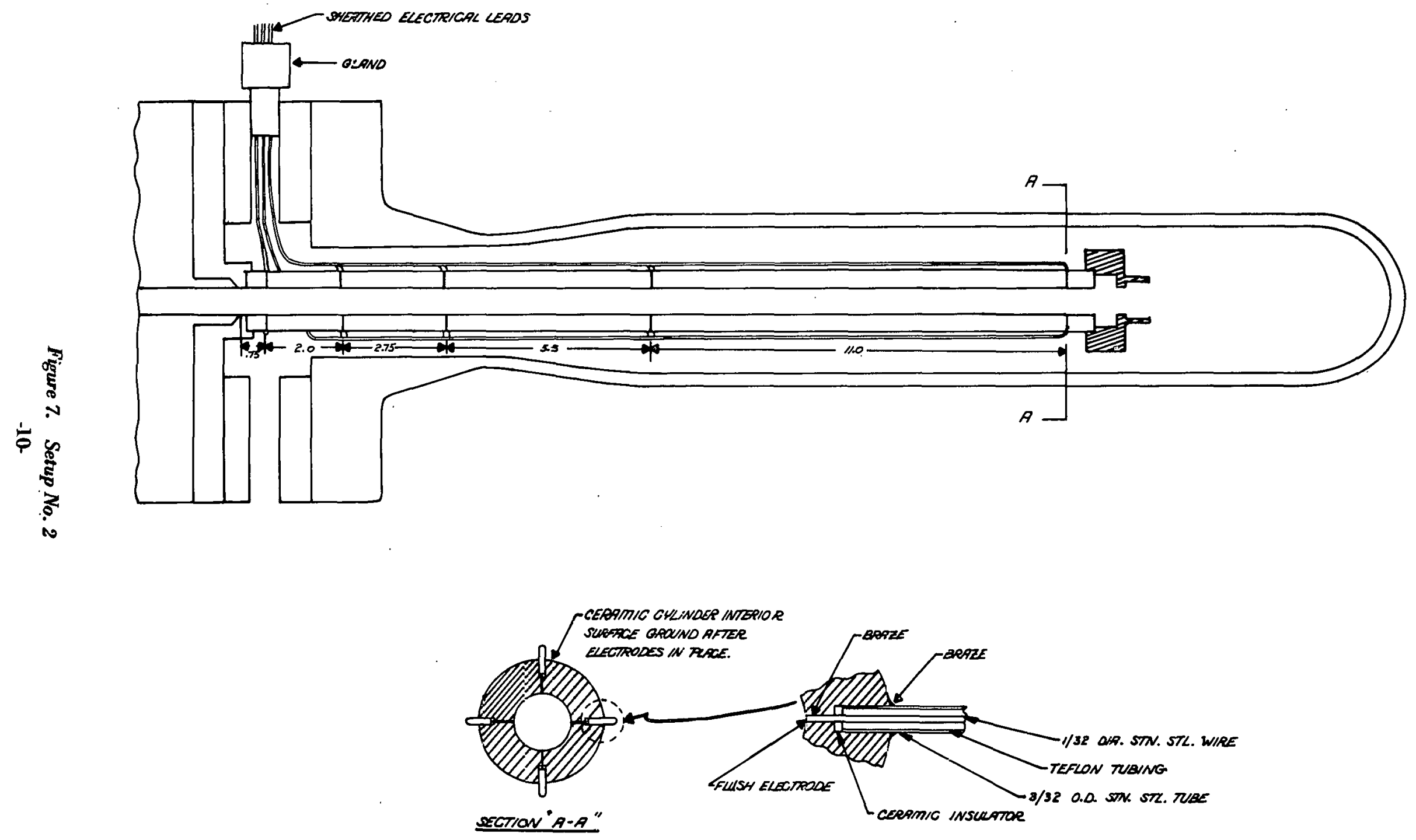

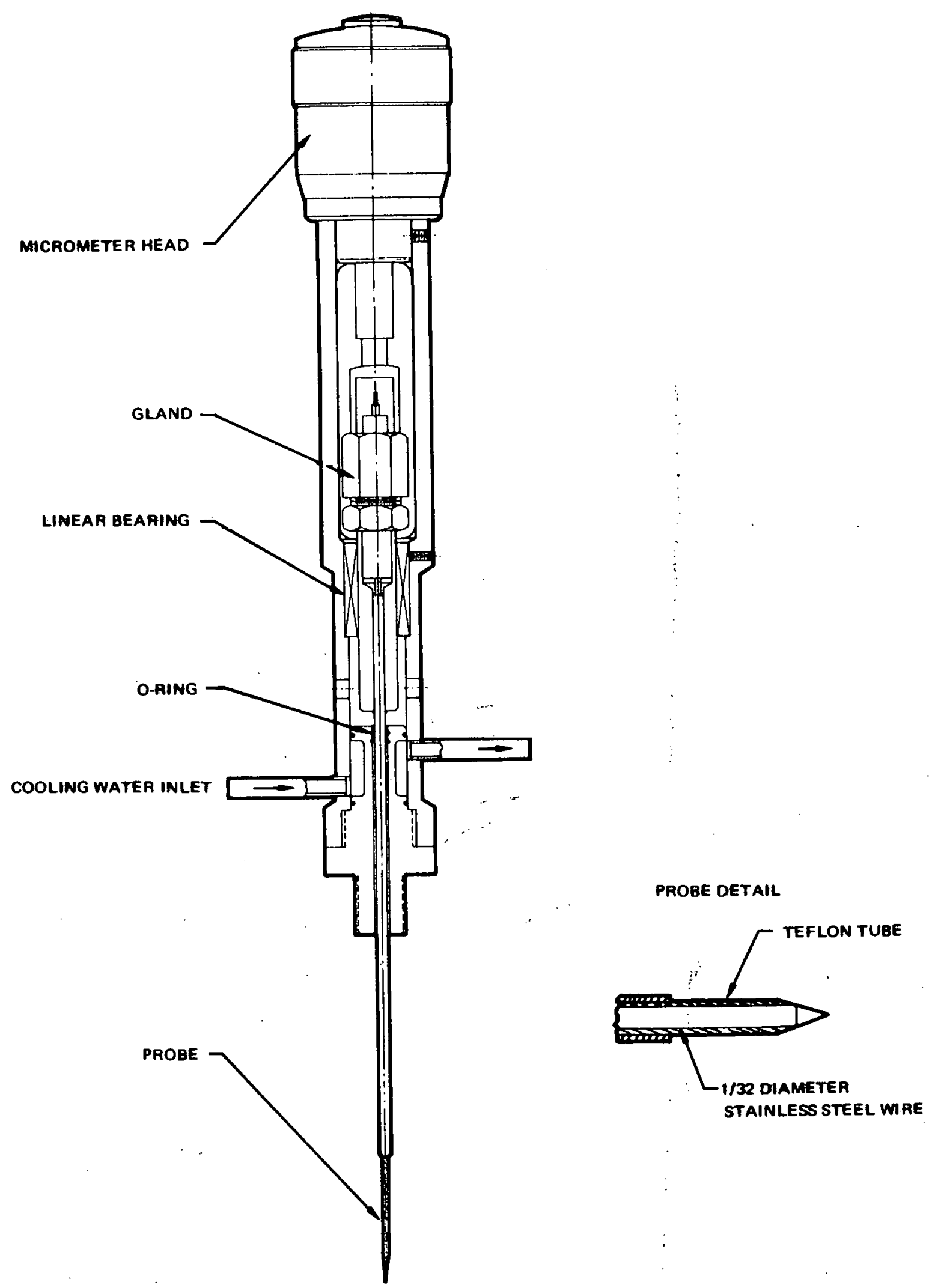

Figure 8. Conductivity Probe

$-11-i$ 
- Inlet tempcrature

- Power to test section

- lixit temperaturc

- (.onductivity cell conductance

(time average and versus time)

- Conductivity probe conductance (versus time)

Various values of inlet temperature and power are used in combination with the various points of power lead attachment, to set the same conditions for which data were obtained in Setup No. 1. The effect on film thickness (as measured by two different methods) is then determined for mass rate, quality, and distance from the end of the heated length. The results can be correlated with the sample flow and pressure gradient measurements made with Setup No. 1.

\section{REFERENCES}

1. Two-Phase Flow and Heat Transfer in Multirod Geometries, Fourteenth Quarterly Progress Report, January 1-March 31,1969, GEAP-10055 (May 1969).

2. Two-Phase Flow and Heat Transfer in Multirod Geometries, Fifteenth Quarterly Progress Report, April 1-June 30, 1969, GEAP-10067 (August 1969).

3. Thornton,J. D., and Bennett, J. A. R., "Data on the Vertical Flow of Air-Water Mixtures in the Annular and Dispersed Flow Regions-Part 1: Preliminary Study," Trans. Inst. Chem. Eng. 39, 101(1961).

4. Collier, J. G., and Hewitt, G. F., "Data on the Vertical Flow of Air-Water Mixtures in the Annular and Dispersed Flow Regions-Part II: Film thickness and Entrainment Data. and Analysis of Pressure Drop Measurements," Trans. Inst. Chem. Eng. 39, 127 (1961).

\section{DISTRIBUTION}

Aerojet-General Corporation

Nuclear Products and Services Group

P.O. Box 77

San Ramon, C.alifonrnia 94.583

Attn: H. Jaffe

Argonne National Laboratory Reactor Engineering Division 9700 South Cass Avenue

Argonne, Illinois 60439

Attn: Dr. Paul Lottess

Argonne. National Laboratory

Reactor Engineering Division

9700 South Cass Avenue

Argonne, Illinois 60439

Attn: M. Petrick

Atomics International

P.0. Box 309

Canoga Park, California 91305

Attn: L. Bernath
5. Hewitt, G. F., King, R. D., and Lovegrove, P. C., Techniques for Liquid Film and Pressure Drop Studies in Annular Two-Phase Flow, AERE R-3921 (March 1962).

6. Collier, J. G., and Hewitt, G. F., Film Thickness Measurements, AERE R-4684 (July 1964).

7. McManus, H. N., Jr., "An Experimental Investigation of Film Characteristics in Horizontal Annular TwoPhase Flow," ASME Paper 57-A-144, presented at ASME Annual Meeting, New York, December 1-6, 1957.

8. Bergles, A. E., Clawson, L. G., Roos, J. P., and Bourne, J. G., Investigation of Boiling Flow Regimes and Critical Heat Flux, Dynatech Quarterly Report (No. 625), NY0-3304-7 (February 1966).
1 Babcock \& Wilcox Company

Atomic Energy Division

P.O. Box 1260

Lynchburg, Virginia 24505

Attn: D.F. Judd

1 Brookhaven National Laboratory

Chemical Engineering Division

Upton, New York 11973

Attn: Dr. O.E. Dwyer

Columbia University

1 Department of Chemical Engineering

New York, New York 10027

Attn: J. Casterline

Combustion Engineering, Inc.
Nuclear Division

P.O. Box 500

Wiudsưi, Connecticut 06095

Attn: Dr. P. Zmola 
F..l. du Pont de Nemours and Company Wilmington, Delaware 19898

Attı: J.S. Neill

Dynatech Corporation

17 Tudor Street

Cambridge, Massachusetts 02139

Attn: A. Bergles

General Electric Company

Research and Development Center

P.O. Box 8

Schenectady, New Yurk 12301

Attn: Fred Staub

Knolls Atomic Power Laboratory

General Electric Company

P.O. Box 1072

Schenectady, New York 12301

Attn: Duiunnent Librarian

Geoscience Limited

410 South Cedros

Solano Beach, California

Attn: H. Poppendick

Massachusetts Institute of Technology

Department of Mechanical Engineering

Cambridge, Massachusctts 02139

Attn: Dr. W. Rohsenow

Massachusetts Institute of Technology

Department of Mechanical Engineering

Cambridge, Massachuset ts 02139

Attn: Dr. P. Griffith

New York University

Department of Mechanical Engineering University Heights

New York, New York 10453

Attn: Dr. Novak Zuber

North Carolina State University Department of Chemical Engineering Kaleigh, North Larolina 27607

Attn: Dr. J.K. Ferrell

A. Amorosi, Director LMFBR Prugrán Office

Argonne National Laboratory

9700 South Cass Avenue

Argonne, Illinois 60439
Pacific Northwest Laboratory

P.O. Box 999

Richland, Washington 99352

Attn: J. Batch

1

Rutgers, The State University

College of Engineering

New Brunswick, New Jersey 08903

Attm: Dr. R.L. Peskin

1

Stanford University

Department of Mechanical Engineering

Stauford, California 94305

Attn: Dr. G. Leppert

1 TRW, Inc.

TRW Systems Group

One Space Park

Redondo Beach, California 90278

Allı. S.M. Zivi

University of Michigan

Department of Chemical and Metallurgical Engineering Ann Arbor, Michigan 48103

Attn: R. Balzhiser

1

Westinghouse Electric Corporation

Atomic Power Division

Box 355

Pittsburgh, Pennsylvania 15230

Altu: L.S. Tong

1

Westinghouse Electric Corporation

Bettis Atomic Power Laboratory

P.0. Box 79

West Mifflin, Pennsylvania 15122

Attn: S. Green

1

National Aeronautics \& Space Admin.

Lewis Research Center

21000 Brookpark Road

Cleveland, Ohio 44135

Attn: R. Weltmann (SEPO)

1 National Aeronautics \& Space Admin.

Lewis Research Center

21000 Brookpark Road

Cleveland, Ohio 44135

Attn: Librarian

1

Oak Ridge National Laboratory 
Atomic Energy of Canada Limited

Chalk River, Ontario, Canada

Attı: G.A. Wikhammer

U.S. Atomic Energy Commission

Division of Reactor Development and Technology

Wushington, D.C. 20545

Attn: R.M. Scroggins

U.S. Atomic Energy Commission

Division of Reactor Development and Technology

Washington,D.C. 20545

Attn: N. Todreas

U.S. Atomic Energy Commission

Division of Reactor Development and Technology.

Washington, D.C. 20545

Attn: Water Projects Branch

U.S. Atomic Energy Commission

Division of Reactor Development and Technology

Washington, D.C. 20545

Attn: Research \& Development Branch

U.S. Atomic Energy Commission

Division of Safety Standards

Washington, D.C. 20545

Attn: R. Impara

Atomic Energy Commission

DTIE

P.O. Box 62

Oak Ridge, Tennessee

Centre d'Etudes Nucleaires

Chemin des Martyrs

Grenuble (Itere)

France

Attn: M. Mondin

\section{CISE}

Casella Postale 3986

Milano (Segrate)

Italy

Attn: Prof. M. Silvestri

MAN

Abholfach

Nurnberg 2

Germany

Attn: Dr. Mayinger
1 SNECMA

Division Atomique

22, Quai Gallieni

Suresnes (Seine)

2 France

Attn: M. Foure

Technische Hogeschool Eindhoven

1 Eindhoven

Netherlands

Attn: Prof. Dr. M. Bogaardt

AEG-Kernenergieversuchsanlage

18752 Grosswelzheim (Unterfranken)

Germany

Attn: Dr. Kirchenmayer

CNEN

1 Rome

Via Belisario, 15

Italy

Attn: M. Bianchi

1. Alsthom

38 avenue Kleber

Paris 16e

France

Attn: M.P. Domenjoud

3

Centre d'Etudes Nucleaires de Saclay

1

B.P. no 2

Gif-sur-Yvette (S\&O)

France

$1 \Lambda \mathrm{ttn}$ : M.J. Horowitz

FIAT

Sezione Energia Nucleare

Via Settembrini 235

Torino

1 Italy

Attn: M.G. Cesoni

Reactor Centrum Nederland 
ANSAIDOO

Direzione ('enerale

l'iazzad Carignano 2

Genova

ttaly

Attn: Dr. F. Cristofori

EURATOM

Direction Generale R\&E

51, rue Belliard

Bruxelles

Belgium

Attn: Dr. P. Kruys
1 EURATOM

Casella Postale 1

Ispra (Varese)

Italy

Attn: M.R. Morin 